\title{
KUALITAS SEMEN KAMBING KACANG DENGAN LAMA SIMPAN YANG BERBEDA PADA SUHU RUANG MENGGUNAKAN PENGENCER TRIS AMINOMETHAN KUNING TELUR
}

\author{
Enike Dwi Kusumawati $^{1}$, Kris Nur Utomo ${ }^{2}$, Aju Tjatur Nugroho Krisnaningsih ${ }^{1}$ dan \\ Syam Rahadi ${ }^{3}$ \\ ${ }^{1}$ Dosen Fakultas Peternakan Universitas Kanjuruhan Malang \\ ${ }^{2}$ Alumnus Fakultas Peternakan Universitas Kanjuruhan Malang \\ ${ }^{3}$ Dosen Jurusan Peternakan Fakultas Peternakan Universitas Halu Oleo, Kendari \\ e-mail : enike@unikama.ac.id
}

\begin{abstract}
ABSTRAK
Penelitian ini bertujuan untuk mengetahui kualitas semen segar kambing Kacang pada penyimpanan yang berbeda pada suhu ruang dengan menggunakan pengencer tris aminomethan kuning telur. Penelitian ini dilakukan di Laboratorium Fakultas Peternakan Universitas Kanjuruhan Malang. Metode penelitian yang digunakan adalah metode percobaan dengan menggunakan Rancangan Acak Lengkap (RAL). Setiap perlakuan semen diulang sebanyak 5 kali. Variabel yang diamati antara lain motilitas, viabilitas dan abnormalitas. Data dianalisis menggunakan Analisis Varian. Apabila diantara perlakuan terdapat perbedaan maka dilanjutkan dengan Uji Beda Nyata Terkecil. Berdasarkan hasil penelitian menunjukkan bahwa kualitas spermatozoa kambing Kacang pada suhu ruang dengan lama simpan yang berbeda dengan menggunakan pengencer menunjukkan adanya perbedaan yang sangat nyata $(\mathrm{P}<0,01)$. Pada pengamatan motilitas dan viabilitas spermatozoa kambing Kacang pada suhu ruang menggunakan pengencer menunjukkan adanya perbedaan yang sangat nyata $(\mathrm{P}<0,01)$. Tetapi pada pengamatan abnormalitas spermatozoa kambing Kacang pada suhu ruang tidak menunjukkan adanya pengaruh penggunaan pengencer serta tidak terdapat pengaruh antara lama simpan dan penggunaan pengencer terhadap abnormalitas spermatozoa kambing Kacang $(\mathrm{P}>0,01)$. Namun terdapat pengaruh yang sangat nyata lama simpan terhadap abnormalitas spermatozoa kambing Kacang. Kesimpulan yang diperoleh dari hasil penelitian yaitu lama simpan yang berbeda pada suhu ruang menggunakan tris aminomethan kuning telur terdapat pengaruh sangat nyata terhadap kualitas semen segar kambing Kacang. Berdasarkan hasil penelitian ini maka disarankan agar penggunaan kuning telur sebagai pengencer tidak lebih dari 9 jam karena dapat menurunkan motilitas dan viabilitas spermatozoa..
\end{abstract}

Kata kunci : Lama Simpan, Kambing Kacang, Pengencer, Spermatozoa, Kualitas Semen

\begin{abstract}
The aim of this research intent to know sperm quality of Kacang goat on different storage time on room temperature using yolk tris aminomethan extender. This research was done at the laboratory of Animal Husbandary faculty at the Kanjuruhan University. The method that was experimental method by using completely randomized design. Each treatment consisted of 10 replications. The Kacang goat sperm quality on room temperature with different storage time using yolk tris aminomethan extender had significant $(\mathrm{P}<0,01)$. This research had high $(\mathrm{P}<0,01)$ sperm motility and viability with different storage time on room temperature using yolk tris aminomethan extender.
\end{abstract}

Key words: Sperm Quality, Kacang Goat, Storage Time, Extender, Sperm

\section{PENDAHULUAN}

Berhasilnya suatu program kegiatan Inseminasi Buatan (IB) pada ternak salah satunya tergantung pada kualitas dan kuantitas semen segar yang diejakulasikan seekor pejantan. Kesanggupan untuk 
mempertahankan kualitas dan memperbanyak volume semen tersebut untuk beberapa saat lebih lama setelah ejakulasi sehingga lebih banyak betina akseptor yang akan diinseminasi.

Dilaporkan oleh Arifiantini dan Purwantara (2010) bahwa presentase motilitas dan viabilitas spermatozoa setiap 24 jam selama 144 jam penyimpanan pada suhu ruang menunjukkan bahwa terjadi penurunan motilitas sebanyak $4,3 \%$ sampai $8,6 \%$ selama setiap 24 jam pengamatan dan penurunan viabilitas antara $5,1 \%$ sampai 5,8\%. Dilaporkan pula oleh Yudi (2008) bahwa daya tahan simpan semen segar berdasarkan motilitas dan viabilitas, setelah 3 dan 9 jam penyimpanan pada suhu ruang berturut - turut adalah $48,33 \pm 10,52 \%$ dan $20,00 \pm 7,98 \%$. Sementara itu, viabilitas dalam waktu simpan yang sama adalah $71,49 \pm 6,32 \%$ dan 50,40 $\pm 7,3 \%$. Perbedaan motilitas dan viabilitas, yang nyata $(\mathrm{P}<0,05)$ antara penyimpanan pada suhu ruang dapat terlihat setelah 3 jam. Semen yang disimpan pada suhu suhu ruang memperlihatkan penurunan motilitas dan viabilitas lebih cepat dari pada semen yang disimpan pada suhu ruang. Sehingga pada setiap titk pengamatan semen yang di simpan pada suhu ruang menunjukan motilitas dan viabilitas nyata lebih tinggi.

Berdasarkan latar belakang tersebut perlu diketahui kualitas semen segar kambing kacang dengan lama simpan yang berbeda pada suhu ruang menggunakan pengencer tris aminomethan kuning telur.

\section{MATERI DAN METODE}

\section{A. Waktu dan Tempat Penelitian}

Penelitian dilakukan di Laboratorium Terpadu Fakultas Peternakan Universitas Kanjuruhan Malang pada tanggal 2- 30 Agustus 2012.

\section{B. Materi Penelitian \\ 1. Bahan Penelitian}

Bahan yang digunakan dalam penelitian ini adalah Semen kambing
Kacang, tris aminomethan kuning telur, pewarna eosin negrosin, NaCL 3\%, kertas pengukur $\mathrm{pH}$.

\section{Peralatan Penelitian}

Alat yang digunakan antara lain mikroskop, timbangan analitik, water bath, thermometer, erlenmeyer, neraca ukur, tissue, magnetik stirer, tabung reaksi, rak tabung reaksi, aluminium foil, mikropipet, object glass dan cover glass, kertas lakmus, gunting, ose, haemocytometer, hand counter, kamar hitung Neubauer. dan Vagina buatan.

\section{Prosedur Penelitian}

1) Prosedur percobaan yang di amati meliputi :

a) Semen segar diamati secara makroskopis (volume, warna, $\mathrm{pH}$ ), Semen segar yang diletakkan pada suhu ruang.

b) Semen segar diamati secara mikroskopis (Motilitas Individu, Viabilitas, Motilitas massa, Konsentrasi, Abnormalitas)

2) Penampungan Semen segar dan Pengamatan

a) Penampungan Semen Menggunakan Vagina Buatan:

Proses penampungan semen meliputi beberapa tahapan, mulai koleksi semen dilaksanakan pada pagi hari dengan menggunakan vagina buatan, dengan mengisi air hangat yang bertemperatur 42$45^{\mathrm{O}} \mathrm{C}$ dan pemberian tekanan udara dengan jalan dipompa dan diberi bahan pelicin yaitu vaselin dioleskan pada liang vagina buatan dengan menggunakan stick glass sepertiga dari panjang vagina buatan, dapat juga menggunakan kambing betina yang sedang birahi sebagai pemancing sampai pada tahap pelaksanaannya di lapang.

Segera setelah penampungan di lakukan evaluasi kuantitatif dan kualitatif terhadap semen segar. Evaluasi kualitatif 
meliputi volume, konsistensi, warna, $\mathrm{pH}$ dan jumlah total spermatozoa sedangkan evaluasi kuantitatif meliputi motilitas massa, motilitas individu, presentase hidup-mati, konsentrasi dan abnormalitas. Tujuan dari evaluasi semen adalah untuk menentukan suatu parameter dalam memprediksi kemampuan fertilitas dari spermatozoa tersebut. Untuk mengetahui apakah semen layak untuk diproses lebih lanjut. Semen yang diencerkan harus memiliki persyaratan, yaitu minimal persentase motilitas $70 \%$, konsentrasi $2 \times 10^{9}$ spermatozoa $/ \mathrm{ml}$ dan persentase abnormalitas kurang dari 15\%.

b) Motilitas Individu Spermatozoa

Pengamatan motilitas individu diamati dengan cara meneteskan satu tetes semen di object glass kemudian ditutup dengan cover glass. Pengamatan di bawah mikroskop dengan pembesaran 400 kali.

c) Persentase Hidup (Viabilitas
spermatozoa)

Persentase hidup diamati dengan pewarnaan eosin-negrosin. Semen diteteskan pada object glass dan ditetesi dengan eosin-negrosin. Setelah dihomogenkan diusap dengan menggunakan cover glass dengan posisi $30^{\circ}$ terhadap sumbu horisontal. Obyek glass diamati dibawah mikroskop dengan pembesaran 400 kali. Spermatozoa yang terang dianggap hidup dan yang berwarna merah gelap dianggap mati. Jumlah spermatozoa yang hidup dihitung dari 200 pengamatan sel spermatozoa, hasilnya dinyatakan dalam persen.

\section{d) Persentase Spermatozoa Abnormal}

Preparat untuk pengamatan abnormalitas seperti preparat pengamatan hidup-mati yang diamati bentuk morfologinya. Jumlah spermatozoa abnormal dihitung dari 200 sel spermatozoa, dan hasilnya dinyatakan dalam persen.

\section{e) Motilitas Massa}

Pengamatan motilitas massa diamati dengan cara meneteskan satu tetes semen di object glass kemudian tempatkan object glass tersebut pada meja objek mikroskop, setelah itu dilakukan pengamatan di bawah mikroskop dengan pembesaran 400 kali.

\section{f) Konsentrasi}

Pengamatan konsentrasi seperma dalam satu contoh semen dapat dihitung secara lebih akurat dengan menggunakan pipet haemacytometer dan kamar hitung Neubauer dengan cara Teteskan satu tetes kecil semen pada permukaan object glass bersih. Hisap semen tersebut ke dalam pipet haemacytometer sampai mencapai angka 0,5 . Kemudian encerkan dengan larutan $\mathrm{NaCl} 3 \%$ sampai mencapai angka 101. Keringkan bagian ujung luar pipet dari cairan dengan kertas tissue. Kocok larutan semen tersebut dengan gerakan angka delapan (8) supaya sperma dalam pipet tercampur secara merata tetapi sel-selnya tidak rusak karena pengocokan yang dilakukan tidak menimbulkan benturan antara sel dengan dinding pipet. Pengocokan dilakukan selama kurang lebih satu menit. Buang tiga tetes cairan dalam pipet. Siapkan kamar hitung Neubauer kemudian diletakkan di atas objek mikroskop pada posisi mendatar. Teteskan semen yang sudah dicampur dengan $\mathrm{NaCl} 3 \%$ pada cover glass dan tutup dengan cover glass kemudian letakkan cover glass tersebut diatas kamar hitung Neubauer yang sudah berada diatas mikoskop yang telah diseting, setelah itu dilakukan pengamatan di bawah mikroskop dengan pembesaran 400 kali.

\section{Rancangan Penelitian}

Penelitian ini dilakukan dengan menggunakan Rancangan Acak Lengkap (RAL) dengan lama simpan yang berbeda pada suhu ruang menggunakan pengencer tris aminomethan kuning telur, pada lama simpan $0,3,6,9,12,15,18,21,24,27,30$ jam, masing-masing diulang $5 \mathrm{x}$.

\section{E. Peubah Penelitian}

Peubah yang diamati dalam penelitian ini adalah motilitas, viabilitas dan abnormalitas. 


\section{F. Analisis Data}

Data yang diperoleh dianalisis menggunakan Analisis Varian. Apabila diantara perlakuan terdapat perbedaan maka dilanjutkan dengan Uji Beda Nyata Terkecil.

\section{HASIL DAN PEMBAHASAN}

\section{A. Kualitas Semen Segar Hasil Evaluasi}

Semen yang digunakan adalah semen segar kambing Kacang hasil penampungan dari seekor kambing Kacang yang didapatkan dari peternakan Bapak Nuryanto,
Kec, Kanigoro, Kab. Blitar, Jawa Timur. Pemeriksaan semen yang dilakukan dalam penelitian ini adalah evaluasi semen secara makroskopis menunjukkan volume sebanyak $1 \mathrm{ml}$, warna semen krem, $\mathrm{pH} 7$ dengan konsistensi sedang. Sedangkan evaluasi secara mikroskopis yang diperoleh berturut-turut yakni gerakan atau motilitas massa sangat bagus $(+++)$, motilitas $(75,2 \%)$, viabilitas $(95,8 \%)$, konsentrasi $\quad\left(3540,2 \times 10^{6}\right) \quad$ dengan abnormalitas spermatozoa (1,6\%). Untuk lebih jelasnya bisa dilihat pada Tabel 1 .

Tabel 1. Hasil evaluasi semen segar kambing Kacang pada penelitian

\begin{tabular}{lll}
\hline \multicolumn{1}{c}{ Pengamatan } & \multicolumn{1}{c}{ Parameter } & \multicolumn{1}{c}{ Rataan } \\
\hline Makroskopis & Volume $(\mathrm{ml})$ & 1 \\
& Bau & Khas \\
& Warna & Krem \\
& Konsistensi & Sedang \\
& pH & 7 \\
\hline Mikroskopis & Motilitas (\%) & 75.2 \\
& Motilitas massa & Sangat bagus $(+++)$ \\
& Viabilitas $(\%)$ & 95.8 \\
& Abnormalitas $(\%)$ & 1,6 \\
& Konsentrasi $\left(10^{6 / \mathrm{ml})}\right.$ & 3540,2 \\
\hline
\end{tabular}

Berdasarkan hasil evaluasi di atas menunjukkan bahwa kualitas semen segar kambing Kacang yang diteliti cukup baik untuk digunakan dan layak untuk diproses lebih lanjut untuk keperluan program inseminasi buatan (IB).

\section{B. Evaluasi Makroskopis}

a) Volume

Volume semen hasil pada penelitian ini $1 \mathrm{ml}$ hal ini masih sesuai dengan Sekosi dkk. (2016) yang menyatakan bahwa volume semen kambing setiap kali ejakulasi berkisar antara 0,5-1,5 ml. Sedangkan menurut Hafez and Hafez (2008), volume semen Kambing berkisar antara 0,5-1,2 ml/ ejakulat. Volume semen berbeda menurut bangsa, umur, ukuran badan, frekuensi penampungan, lingkungan, kondisi dari ternak itu sendiri, waktu penampungan dan pakan.

b) $\mathrm{Bau}$

Bau semen yang dihasilkan pada penelitian ini adalah bau khas sperma yaitu berbau amis khas sperma. Hal ini sesuai dengan Kusumawati dkk. (2016 $)$ yang mengemukakan bahwa semen yang normal umumnya memiliki bau amis khas disertai bau dari hewan itu sendiri. Bau busuk bisa terjadi apabila semen mengandung nanah yang disebabkan oleh adanya infeksi organ atau saluran reproduksi hewan jantan.

c) Warna

Warna semen yang diperoleh pada penelitian ini adalah krem, hal ini sesuai dengan Sekosi et al. (2016) yang mengemukakan bahwa warna semen segar 
kambing yang normal adalah putih hingga krem. Semen pada penelitian ini dapat dikatakan normal dikarenakan tidak ada campuran warna kemerahan dan warna coklat yang menandakan semen terkontaminasi darah, ataupun warna kehijauan yang merupakan tanda adanya bakteri pembusuk dalam semen. Ini sesuai dengan Ax et al. (2008) yang menyatakan bahwa bila semen berwarna kemerahan adalah tanda bahwa semen terkontaminasi oleh darah segar, sedang apabila warnanya mendekati coklat dapat merupakan tanda bahwa darah yang mengkontaminasi semen sudah mengalami dekomposisi. Warna kehijauan merupakan tanda adanya bakteri pembusuk dalam semen.

\section{d) Konsistensi (Kekentalan)}

Pada penelitian ini konsistensi semen yang diamati adalah sedang. Hal ini menunjukkan bahwa semen yang diteliti pada penelitian ini masih dalam taraf kekentalan yang normal ini dikarenakan kekentalan semen yang diteliti sedikit lebih kental dari susu. Hal ini sesuai dengan pendapat Zenichiro, dkk. (2002) bahwa semen yang baik derajat kekentalannya hampir sama atau sedikit lebih kental dari susu, sedangkan yang jelek baik warna maupun kekentalannya sama dengan air kelapa.

\section{e) Derajat Keasaman $(\mathrm{pH})$}

Derajat keasaman memegang peranan sangat penting karena dapat mempengaruhi viabilitas spermatozoa. Apabila $\mathrm{pH}$ tinggi/rendah akan menyebabkan spermatozoa mati. Derajat keasaman hasil penelitian adalah 7, hal ini masih lebih tinggi menurut Sekosi dkk. (2016) yang menyebutkan derajat keasaman $(\mathrm{pH})$ semen umumnya pada kisaran 6,4-6,8\%. Tetapi $\mathrm{pH}$ 7 pada semen yang diteliti termasuk pada kisaran $\mathrm{pH}$ netral dan begitu juga dengan derajat keasaman semen pada umumnya pada kisaran $\mathrm{pH}$ netral.

\section{Evaluasi Mikroskopis}

\section{Motilitas Spermatozoa Kambing Kacang Pada Suhu Ruang}

a) Motilitas Massa

Semakin tinggi skala gerakan atau motilitas massa, maka kualitas sperma semakin baik. Motilitas massa hasil penelitian adalah sangat bagus $(+++)$. Gelombang yang terlihat berbentuk besarbesar dan bergerak sangat cepat dan padat. Tidak tampak sperma secara individual. Hal ini sesuai dengan penilaian Ax et al. (2008) yang menyatakan bahwa penilaian Sangat bagus mempunyai skor 5 dengan keterangan terlihat sangat padat, gelombang yang terbentuk besar-besar dan bergerak sangat cepat. Tidak tampak sperma secara individual, semen tersebut mengandung $90 \%$ atau lebih sperma aktif.

b) Motilitas Individu

Pada penelitian ini rataan motilitas individu yang didapat adalah $75.2 \%$, nilai ini lebih rendah dibandingkan penelitian Kaka (2010) yaitu rataan persentase motilitas semen segar kambing PE adalah 76,67\%. Adapun faktor - faktor yang mempengaruhi motilitas sperma menurut Ax et al. (2008) adalah metode penampungan semen, lingkungan, penanganan dan perawatan semen sesudah penampungan, interval antara penampungan dan evaluasi semen, variasi pejantan serta variasi musim. Faktorfaktor tersebut yang menyebabkan adanya perbedaan hasil motilitas sperma dari setiap pejantan kambing Kacang dan ternak ternak-ternak pejantan lain.

Berdasarkan hasil evaluasi semen segar kambing Kacang seperti terlihat pada Tabel 1. dapat diketahui bahwa semen dalam penelitian ini mempunyai kualitas yang baik. Hal ini ditunjukkan dengan presentase motilitas spermatozoa sebesar $75,2 \%$, sehingga semen ini bisa diproses lebih lanjut untuk keperluan IB. Hal ini sesuai dengan pendapat Zenichiro dkk. (2002) dan Kusumawati and Leondro (2015) menyatakan bahwa semen segar harus memiliki motilitas $\geq 70 \%$ agar dapat 
diproses lebih lanjut menjadi semen beku untuk keperluan IB.

Hasil penelitian semen segar pada suhu ruang dengan menggunakan pengencer menunjukkan rataan persentase motilitas spermatozoa tertinggi pada lama simpan ke
0 jam yaitu sebesar $75,2 \pm 0,84 \%$, dan untuk motilitas terendah terjadi pada lama simpan ke 30 jam yaitu dengan rataan persentase $0 \pm 0,00 \%$. Untuk lebih jelasnya dapat dilihat pada Tabel 2.

Tabel 2. Rataan Persentase Motilitas Spermatozoa pada Lama Simpan yang Berbeda

\begin{tabular}{cc}
\hline Lama simpan & Motilitas $(\%)$ \\
\hline 0 jam & $75,2 \pm 0,84^{\mathrm{a}}$ \\
3 jam & $73,6 \pm 1,52^{\mathrm{a}}$ \\
6 jam & $71,8 \pm 1,92^{\mathrm{a}}$ \\
9 jam & $67 \pm 1,58^{\mathrm{b}}$ \\
$12 \mathrm{jam}$ & $58,2 \pm 2,95^{\mathrm{c}}$ \\
$15 \mathrm{jam}$ & $54 \pm 4,53^{\mathrm{d}}$ \\
18 jam & $22,2 \pm 4,49^{\mathrm{d}}$ \\
21 jam & $5,4 \pm 2,88^{\mathrm{e}}$ \\
24 jam & $3 \pm 1,58^{\mathrm{f}}$ \\
27 jam & $0,8 \pm 0,8^{\mathrm{f}}$ \\
30 jam & $0 \pm 0^{\mathrm{f}}$
\end{tabular}

Keterangan: Notasi yang berbeda menunjukkan adanya perbedaan yang sangat nyata $(\mathrm{P}<0,01)$

Berdasarkan analisis data menunjukkan bahwa motilitas spermatozoa kambing Kacang pada suhu ruang dengan lama simpan yang berbeda dengan menggunakan pengencer menunjukkan adanya perbedaan yang sangat nyata $(\mathrm{P}<0,01)$. Pada lama simpan $0,3,6,9,12$ dan 15 jam dengan menggunakan pengencer rataan motilitas spermatozoa masih berada dalam kisaran standar minimum untuk program IB yaitu berkisar antara 54-95\%. Hal ini sesuai dengan pendapat Kusumawati dkk. $\left(2016^{\mathrm{a}}\right)$ yang menyatakan bahwa salah satu standar minimum bagi kualitas semen yang dapat dipakai untuk inseminasi buatan adalah minimal mengandung $50 \%$ persentase sperma hidup (viabilitas) dan yang motil. Ini berarti pada lama simpan 18, 21, 24,27 dan 30 jam yang rataan motilitas spermatozoa berkisar antara $0-50 \%$ tidak dapat dilakukan proses lebih lanjut karena di bawah standar minimum untuk program IB. Walaupun pada perlakuan dengan menggunakan pengencer motilitas spermatozoa masih terlihat sampai lama simpan ke 27 jam tetapi antara lama simpan ke 18-27 jam tersebut rataan persentase motilitas spermatozoa berada dalam kisaran di bawah $50 \%$ yang berarti tidak dapat dilakukan proses lebih lanjut karena di bawah standar minimum untuk program IB (Saili dkk., 2017).
Hal ini diduga kerena pengencer yang mengandung kuning telur sudah mulai membusuk, ini terbukti pada lama simpan ke 15 jam timbul aroma yang menyengat. Hal inilah yang menyebabkan motilitas spermatozoa mulai menurun drastis hingga mencapai $0 \%$. Semakin lama waktu penyimpanan berarti energi yang dibutuhkan spermatozoa semakin tinggi sedangkan nutrisi yang tersedia dalam semen semakin berkurang. Susilawati (2014) menambahkan faktor penyesuaian suhu dari suhu tubuh ternak ke suhu ruang dapat juga mempengaruhi pergerakan spermatozoa karena spermatozoa harus mampu menyesuaikan kondisi fisik dengan lingkungan. Dengan demikian terdapat pengaruh lama simpan yang berbeda dengan menggunakan pengencer terhadap motilitas spermatozoa kambing Kacang pada suhu ruang.

Viabilitas Spermatozoa Kambing Kacang Pada Suhu Ruang

Persentase viabilitas sperma pada penelitian ini adalah $95.8 \%$, nilai ini lebih besar dibandingkan penelitian Kaka (2010) yaitu sebesar $81,45 \%$ pada kambing Peranakan Ettawa (PE). Berdasarkan hasil 
evaluasi semen segar kambing Kacang seperti terlihat pada Tabel 1. dapat diketahui bahwa semen dalam penelitian ini mempunyai kualitas yang baik. Hal ini ditunjukkan dengan presentase viabilitas spermatozoa sebesar 95,8\%, sehingga semen ini bisa diproses lebih lanjut untuk keperluan IB. Hal ini sesuai dengan pendapat Kusumawati dkk. (2016 ${ }^{\mathrm{a}}$ ) yang menyatakan bahwa salah satu standar minimum bagi kualitas semen yang dapat dipakai untuk inseminasi buatan adalah minimal mengandung 50\% persentase sperma hidup (viabilitas) dan yang motil.

Hasil penelitian semen segar pada suhu ruang dengan menggunakan pengencer menunjukkan rataan persentase viabilitas spermatozoa tertinggi pada lama simpan ke 0 jam yaitu sebesar $95,8 \pm 0,8 \%$, dan untuk viabilitas terendah terjadi pada lama simpan ke 30 jam yaitu dengan rataan persentase $0 \pm 0 \%$. Untuk lebih jelasnya dapat dilihat pada Tabel 3.
Berdasarkan analisis data menunjukkan bahwa viabilitas spermatozoa kambing Kacang pada suhu ruang dengan lama simpan yang berbeda dengan menggunakan pengencer menunjukkan adanya pengaruh yang sangat nyata $(\mathrm{P}<0,01)$. Pada lama simpan $0,3,6,9,12$ dan 15 jam dengan menggunakan pengencer rataan viabilitas spermatozoa masih berada dalam kisaran standar minimum untuk program IB yaitu berkisar antara 54-95\%. Hal ini sesuai dengan pendapat Kusumawati et al. (2015) yang menyatakan bahwa salah satu standar minimum bagi kualitas semen yang dapat dipakai untuk inseminasi buatan adalah minimal mengandung 50\% persentase sperma hidup (viabilitas) dan yang motil. Ini berarti pada lama simpan 18, $21,24,27$ dan 30 jam yang rataan viabilitas spermatozoa berkisar antara $0-50 \%$ tidak dapat dilakukan proses lebih lanjut karena di bawah standar minimum untuk program IB.

Tabel 3. Rataan Persentase Viabilitas Spermatozoa ada

Lama Simpan yang Berbeda

\begin{tabular}{cc}
\hline Lama simpan & $\begin{array}{c}\text { Rataan } \\
\text { Viabilitas }(\%)\end{array}$ \\
\hline 0 jam & $95,8 \pm 0,8^{\mathrm{a}}$ \\
3 jam & $95,2 \pm 0,8^{\mathrm{a}}$ \\
6 jam & $92,6 \pm 1,1^{\mathrm{a}}$ \\
9 jam & $90,8 \pm 0,8^{\mathrm{b}}$ \\
12 jam & $82,2 \pm 2,4^{\mathrm{c}}$ \\
15 jam & $59 \pm 3,88^{\mathrm{d}}$ \\
18 jam & $24,8 \pm 4,3^{\mathrm{e}}$ \\
21 jam & $7,4 \pm 1,5^{\mathrm{f}}$ \\
24 jam & $2,8 \pm 1,3^{\mathrm{f}}$ \\
27 jam & $0,8 \pm 0,8^{\mathrm{g}}$ \\
30 jam & $0 \pm 0^{\mathrm{g}}$ \\
\hline Keterangan: Notasi yang berbeda menunjukkan adanya pengaruh
\end{tabular}
yang sangat nyata $(\mathrm{P}<0,01)$. 
Perlakuan dengan menggunakan pengencer viabilitas spermatozoa masih terlihat sampai lama simpan ke 27 jam akan tetapi antara lama simpan ke 18-27 jam tersebut rataan persentase viabilitas spermatozoa berada dalam kisaran di bawah $50 \%$ yang berarti tidak dapat dilakukan proses lebih lanjut karena di bawah standar minimum untuk program IB sesuai menurut Kusumawati et al. (2017). Hal ini diduga kerena pengencer yang mengandung kuning telur sudah mulai membusuk, ini terbukti pada lama simpan ke 15 jam timbul aroma yang menyengat. Hal inilah yang menyebabkan viabilitas spermatozoa mulai menurun drastis hingga mencapai $0 \%$.

Penurunan persentase viabilitas spermatozoa ini dikarenakan persediaan nutrisi spermatozoa yang hanya berasal dari seminal plasma saja tanpa adanya tambahan nutrisi dari medium lain. Semakin lama waktu penyimpanan, nutrisi dalam seminal plasma semakin berkurang hal ini yang menyebabkan persentase viabilitas spermatozoa kambing Kacang pada suhu ruang semakin lama semakin menurun.

Semakin lama waktu penyimpanan berarti energi yang dibutuhkan spermatozoa semakin tinggi sedangkan nutrisi yang tersedia dalam semen semakin berkurang. Susilawati (2014) menambahkan faktor penyesuaian suhu dari suhu tubuh ternak ke suhu ruang dapat juga mempengaruhi pergerakan spermatozoa karena spermatozoa harus mampu menyesuaikan kondisi fisik dengan lingkungan. Dengan demikian terdapat pengaruh lama simpan yang berbeda menggunakan pengencer terhadap viabilitas semen segar kambing Kacang pada suhu ruang.

\section{Abnormalitas Spermatozoa Kambing Kacang Pada Suhu Ruang}

Persentase sperma abnormal pada penelitian ini adalah $2,9 \%$, nilai ini sesuai dengan standar Inseminasi Buatan menurut Sekosi dkk. (2016) yang menyatakan bahwa semen untuk keperluan inseminasi buatan sebaiknya tidak mengandung sperma abnormal lebih dari $20 \%$. Sedangkan menurut Saili dkk. (2016) bahwa standar persentase abnormalitas spermatozoa kambing yang layak digunakan untuk IB tidak lebih dari $15 \%$. Dengan persentase abnormal 2,9\% semen ini dianggap mempunyai kualitas baik karena hal ini sesuai dengan pendapat Arifiantini dan Purwantara (2010) yang menyatakan bahwa Pada umumnya bila terlihat sel dengan bentuk abnormal yang primer berjumlah $20 \%$ atau lebih maka kualitas semen itu dianggap jelek. Susilawati (2014), standar minimum bagi kualitas semen yang dapat dipakai untuk inseminasi buatan adalah minimal mengandung 500 juta $\mathrm{sel} / \mathrm{ml} /$ ejakulat dengan gerakan massa sangat bagus/bagus $(++/+++)$, serta $50 \%$ persentase sperma yang hidup dan motil.

Berdasarkan karakteristik semen segar tersebut diatas, maka dapat dikatakan bahwa semen kambing Kacang yang digunakan dalam penelitian ini memiliki kualitas semen yang baik dan memenuhi syarat untuk diproses lebih lanjut sehingga dapat digunakan dalam program IB.

Berdasarkan hasil evaluasi semen segar kambing Kacang seperti terlihat pada Tabel 1. dapat diketahui bahwa semen dalam penelitian ini mempunyai kualitas yang baik. Hal ini ditunjukkan dengan presentase abnormalitas spermatozoa sebesar 1,6\%, sehingga semen ini bisa diproses lebih lanjut untuk keperluan IB. Karena hal ini sesuai dengan pendapat Ax at al. (2008) bahwa standar persentase abnormalitas spermatozoa kambing yang layak digunakan untuk IB tidak lebih dari $15 \%$. Sedangkan menurut Karatasudjana (2001) semen untuk keperluan inseminasi buatan sebaiknya tidak mengandung sperma abnormal lebih dari $20 \%$.

Hasil penelitian semen segar pada suhu ruang dengan menggunakan pengencer menunjukkan rataan persentase abnormalitas spermatozoa tertinggi pada lama simpan ke 30 jam yaitu sebesar $11,8 \pm 1,3 \%$, dan untuk abnormalitas terendah terjadi pada lama simpan ke 0 jam yaitu dengan rataan persentase $1,6 \pm 0,89 \%$. 
Untuk lebih jelasnya dapat dilihat pada Tabel 4.

Tabel 4. Rataan Persentase Abnormalitas Spermatozoa pada Lama Simpan yang Berbeda

\begin{tabular}{cc}
\hline Lama simpan & Abnormalitas (\%) \\
\hline 0 jam & $1,6 \pm 0.89^{\mathrm{a}}$ \\
3 jam & $2 \pm 1^{\mathrm{a}}$ \\
6 jam & $2,2 \pm 0,8^{\mathrm{a}}$ \\
9 jam & $3,4 \pm 1,14^{\mathrm{a}}$ \\
12 jam & $5,2 \pm 1,3^{\mathrm{b}}$ \\
15 jam & $5,8 \pm 0,8^{\mathrm{b}}$ \\
18 jam & $6,8 \pm 1,3^{\mathrm{b}}$ \\
21 jam & $9 \pm 1,2^{\mathrm{c}}$ \\
24 jam & $9,4 \pm 1,14^{\mathrm{c}}$ \\
27 jam & $10,8 \pm 1,3^{\mathrm{c}}$ \\
30 jam & $11,8 \pm 1,3^{\mathrm{c}}$
\end{tabular}

Keterangan : Notasi yang berbeda menunjukkan adanya pengaruh yang sangat nyata $(\mathrm{P}<0,01)$

Berdasarkan analisis data menunjukkan bahwa abnormalitas spermatozoa kambing Kacang pada suhu ruang dengan lama simpan yang berbeda menunjukkan adanya perbedaan yang sangat nyata $(\mathrm{P}<0,01)$. Pada lama simpan ke 0-30 jam dengan menggunakan pengencer menunjukkan bahwa rataan abnormalitas spermatozoa kambing Kacang pada suhu ruang masih berada dalam kisaran standar minimum untuk program IB tidak lebih dari $15-20 \%$ yaitu berkisar antara 1-11\%. Walaupun mengalami peningkatan tetapi rataan persentase abnormalitasnya tidak lebih dari $15 \%$. Hal ini sesuai dengan pendapat Ax et al. (2008) bahwa standar persentase abnormalitas spermatozoa kambing yang layak digunakan untuk IB tidak lebih dari 15\% . Sedangkan menurut Sekosi dkk. (2016) semen untuk keperluan inseminasi buatan sebaiknya tidak mengandung sperma abnormal lebih dari $20 \%$. Meningkatnya abnormalitas spermatozoa ini dikarenakan semakin menurunnya motilitas spermatozoa karena semakin berkurangnya nutrisi yang dibutuhkan oleh spermatozoa.

Tidak terdapat pengaruh pengencer terhadap abnormalitas spermatozoa kambing Kacang pada suhu ruang. Dan tidak terdapat pengaruh antara lama simpan dan pengencer terhadap abnormalitas spermatozoa kambing Kacang pada suhu ruang, tetapi terdapat pengaruh yang sangat nyata lama simpan terhadap abnormalitas spermatozoa kambing Kacang pada suhu ruang.

\section{KESIMPULAN}

Berdasarkan hasil penelitian dapat disimpulkan bahwa lama simpan yang berbeda pada suhu ruang menggunakan tris aminomethan kuning telur memberikan pengaruh sangat nyata terhadap kualitas semen segar kambing kacang.

\section{DAFTAR PUSTAKA}

Arifiantini, R.I., dan B. Purwantara. 2010. Motility and Viability of Friesian Holstein Spermatozoa In Three Different Extender Stored At $5^{\circ} \mathrm{C}$. Jurnal of the Indonesian Tropical Animal Agriculture. Vol. 35 No. 4 Desember 2010.

Ax, R. L., M. R. Dally, B. A.Didion, R. W. Lenz, C.C. Love, D. D. Varner, B. Hafez and M. E Bellin. 2008 Artifical Ainsemination. In: Hafez E.S.E and Hafez B., editors. Reproduction In Farm Animals $7^{\text {th }}$ ed. Australia Blackwell Publishing. pp: 365-375.

Hafez, E. S. E., and B. Hafez. 2008. X and $Y$ Chromosome-Bearing Spermatozoa. In: Hafez E.S.E and Hafez B., editors. Reproduction In Farm Animals $7^{\text {th }}$ ed. Australia: Blackwell Publishing. pp: 390-394.

Kaka, A. 2010. Evaluasi Semen Kambing Peranakan Etawah. Universitas Nusa Cendana. Kupang.

Kusumawati, E. D. and H. Leondro. 2015. The Quality of Fresh Semen of Bulls at $5^{0} \mathrm{C}$ and $24^{\circ} \mathrm{C}$ With or Without Diluent. In Proceeding International 
Seminar Improving Tropical Animal Production For Food Security. 1(1):122-126.

Kusumawati, E. D., H. Leondro, T. Susilawati, dan N. Isnaini. 2015. Spermatozoa Viability of Filial Ettawa Goat After Sexing Process. In Proceeding International Seminar Improving Tropical Animal Production For Food Security. 1(1):127-130.

Kusumawati, E. D., A. T. N. Krisnaningsih, and R.R. Romadlon. 2016 ${ }^{\mathrm{a}}$. Kualitas Spermatozoa Semen Beku Sapi Simental dengan Suhu dan Lama Thawing yang Berbeda. Jurnal IlmuIlmu Peternakan, 26(3): 38-41.

Kusumawati, E. D., H. Leondro, A. T. N. Krisnaningsih, T. Susilawati, N. Isnaini, and R. Widhad. 2016 . Pengaruh Suhu dan Lama Simpan Semen Segar terhadap Motilitas dan Abnormalitas Spermatozoa Kambing Peranakan Etawa (PE). In Seminar Nasional Hasil Penelitian. 4(1):199208.

Kusumawati, E. D., N. Isnaini, A. P. Y. Yekti, M. Luthfi, L. Affandhy, D. Pamungkas, Kuswati, A. Ridhowi, H. Sudarwati, T. Susilawati, and S. Rahayu. 2017. The Quality Of Sexed Semen on Filial Ongole Bull Using Percoll Density Gradient Centrifugation Method. Asian Journal of Microbiology, Biotechnology \& Environmental Sciences Paper, 19(1):199-203.

Saili, T., L. O. Baa, L. O. A. Sani, S. Rahadi, I. W. Sura, and F. Lopulalan. 2016. Sinkronisasi Estrus dan Inseminasi Buatan Menggunakan Semen Cair Hasil Sexing pada Sapi Bali Induk Yang Dipelihara dengan Sistem yang Berbeda (Oestrus Syncronization and Artificial Insemination using Sexing Semen from Bali's Cattle with
Different Management System). Jurnal Ilmu Ternak. 16(2):49-55.

Sekosi, P. P. P., Kusumawati, E. D., dan Krisnaningsih, A. T. N. 2016 Motilitas dan Viabilitas Semen Segar Kambing Peranakan Etawa (PE) dengan Menggunakan Pengencer Cauda Epididymal Plasma (CEP-2) pada Lama dan Suhu Simpan yang Berbeda. Jurnal Sains Peternakan. 4(1): 34-49.

Susilawati, T. 2014. Sexing Spermatozoa (Hasil Penelitian Laboratorium dan Aplikasi pada Sapi dan Kambing). Universitas Brawijaya Press. Malang.

Yudi, I. Arifiantini, B. Purwantara, dan I. Yusuf. 2008. Daya Tahan Semen Segar dan Kualitas Semen Cair Kuda dengan Konsentrasi Spermatozoa yang Berbeda dalam Pengencer Dimitropoulus yang Dimodifikasi. JITV 13 (1): 35-42.

Zenichiro, K., Herliantien dan Sarastina. 2002. Teknologi Prosesing Semen Beku Pada Sapi. Balai Besar Inseminasi Buatan Singosari. Malang. 